\title{
APRESENTAÇÃO DO DOSSIÊ "OFÍCIOS E PROFISSÕES: MEMÓRIA SOCIAL, IDENTIDADES E CONSTRUÇÃO DE ESPAÇOS DE SOCIABILIDADE”
}

\author{
Fernanda Valli Nummer (D)
}

Maria Cristina Caminha de Castilhos França (D) 
Nesta edição da Amazônica - Revista de Antropologia, apresentamos a segunda produção resultante da quarta edição do Grupo de Trabalho (GT) intitulado "Ofícios e profissões: memória social, identidades e construção de espaços de sociabilidade", ocorrida na $31^{\text {a }}$ Reunião Brasileira de Antropologia (RBA), em Brasília, em dezembro de 2018. A publicação destes resultados está organizada na estrutura de um dossiê, cujo suporte é exclusivamente online.

O principal objetivo deste dossiê é compartilhar pesquisas desenvolvidas nos temas a que o GT se propõe, a fim de fornecer subsídios para reflexões sobre etnografia, visando o enriquecimento e a atualização das temáticas em meio às mazelas que o mundo do trabalho tem enfrentado no atual momento político brasileiro.

Nesse cenário, expor este tema e propor reflexão sobre aspectos que transitam entre ofícios e profissões são situações que reiteram o que o Prof. Giovanni Alves afirma, de forma precisa, no prefácio sob o título "Animal laborens e Homo faber" ao livro que organizamos, ainda na primeira produção do GT:

[...] resgatar a experiência oculta do Homo faber nas narrativas do trabalho significa demonstrar que, apesar do processo de especialização e fragmentação do sujeito que trabalha, existe (e persiste), nos interstícios do mundo vivido de homens e mulheres que trabalham em ofícios e profissões, narrativas de resistências e memória [que] expõem o outro lado da condição humana salientada por Hanna Arendt: a experiência do Homo faber (Alves 2015:14).

Ou seja, o contraste entre o Animal laborens (trabalhador meramente braçal) e o Homo faber (trabalhador reflexivo) compreende o trabalho humano na sua dimensão histórica e resultante das relações sociais: locus da aprendizagem de práticas, que são vivenciadas e reproduzidas. Nessa aparente contradição, estrutura-se o movimento dialético entre a forma social, que determina a consciência - e pela qual se aprende a ser homem -, e as formas de consciência, que produzem o mundo no qual se vive.

Esse, então, é o contexto que configura o GT "Ofícios e profissões: memória social, identidades e construção de espaços de sociabilidade", da $31^{\text {a }}$ RBA: a centralidade do trabalho no processo de humanização, produzida histórica e coletivamente pelo conjunto dos homens; bem como os efeitos do capitalismo e a memória de antigos ofícios/ profissões, que resistem, definindo estilos de vida e estabelecendo espaços de sociabilidade, por meio das teias de relações que marcam identidades sociais.

Em "A concepção dos Institutos Federais e seus atores sociais: a história narrada por trás da história", de Silvia Schiedeck e Maria Cristina Caminha de Castilhos França, a educação profissional no Brasil é discutida por meio da criação dos Institutos Federais de Educação. O resgate da memória de dois importantes personagens que atuaram nas políticas de implementação deste novo campo de profissionalização no país é o foco do estudo.

Daniel Attianesi reconstrói os espaços de uma profissão predominantemente masculina, a 
das agentes penitenciárias do Instituto Penal de Campo Grande, no Mato Grosso do Sul, no artigo intitulado "A construção das feminilidades nos discursos das agentes penitenciárias do Instituto Penal de Campo Grande, Mato Grosso do Sul, Brasil”, percebendo que tanto o ambiente quanto a profissão, em uma instituição total, fazem com que as mulheres esquadrinhem alternativas para exercer suas feminilidades.

"De lá para cá: classe, raça e gênero em narrativas autobiográficas de antropólogas em memoriais acadêmicos (USP/UNICAMP, 2004-2014)", de Wilton Carlos Lima da Silva e Rafaela Duarte Vieira, é um artigo que retoma os memoriais acadêmicos como lugares de narrativas de memórias, de história de vida e de trabalho, para nos fazer compreender como cada intelectual conta sua autobiografia, relacionando pessoas, produções acadêmicas, vida pessoal, sociabilidades...

Em "Etnografias da duração e os desejos de memória ferroviária no Sul do Brasil", os autores Guillermo Stefano Rosa Gómez, Yuri Schönardie Rapkiewicz e Cornelia Eckert resgatam memórias nas narrativas dos ferroviários aposentados, por meio da criação de uma comunidade interpretativa, desenvolvida a partir da desativação das ferrovias brasileiras.

A aprendizagem do ofício de marceneiro é o tema de "Família, criatividade e prazer no ofício: etnografia da aprendizagem em uma marcenaria na Amazônia”, de Luiz Francisco Loureiro, Ana Claudeise Silva do Nascimento, Marilia de Jesus da Silva e Sousa e Nelissa Peralta. A técnica, os valores e os materiais são relatados a partir de um estudo de caso desenvolvido no interior do estado do Pará.
A empresa VARIG é o centro do enredo que reúne ex-trabalhadores da área da aviação civil no artigo "Memórias, disputas de sentido e transformações sociais: as estratégias e as trajetórias dos ex-trabalhadores da VARIG dez anos após sua venda”, de Madhiana Valéria Almeida Rodrigues. Memórias entristecidas e regozijantes misturam-se nas lembranças de honra e no esquecimento destes trabalhadores.

O Teatro Popular União e Olho Vivo, em São Paulo, revive desde os anos 60, a mesma cultura do teatro popular. As relações de trabalho para a manutenção desta arte passaram por mudanças que ficaram na memória de seus fundadores, e este é o tema central de "O ofício teatral no contexto de transformações urbanas: a experiência do Teatro Popular União e Olho Vivo", de autoria de Ana Paula Parodi Eberhardt.

Suiá Omim faz uma densa etnografia visual das obras de Edson Meirelles, fotógrafo e pesquisador carioca, buscando definir seu ofício de pintor ou designer gráfico, no artigo "Pintor ou designer popular: a etnografia de um ofício através do acervo de Edson Meirelles".

Na seção de relatos de pesquisa, a edição traz os objetivos de um estudo que vem sendo realizado na Universidade Federal do Pará por Fernanda Valli Nummer sobre a família fundadora da empresa Phebo, do ramo de perfumaria, cujo título é "“Odor de rosas': família e memória da Phebo em Belém”.

Já na seção de ensaio fotográfico, é apresentada uma antropologia de imagens antigas sobre as atividades de garimpeiros que ainda estavam na ativa na região de Tapajós. Esta contribuição é intitulada de "Conexões entre imagem fotográfica e memória social do garimpo", sendo de autoria de 
Carlos de Matos Bandeira Junior e Rubens Elias da Silva.

O dossiê "Ofícios e profissões: memória social, identidades e construção de espaços de sociabilidade", ora publicado, tem, portanto, a perspectiva de contribuir para a compreensão da complexidade que envolve o mundo do trabalho, circulando entre os conceitos de ofício e profissão, por meio de diferentes espaços e limites de grupos profissionais e de suas trajetórias histórico-sociais. Sabemos que os temas propostos não se esgotam nesta edição da revista, mas entendemos que o presente número preenche lacunas abertas resultantes de grupos profissionais que prospectam sentidos a espaços construídos e vivificados pelas narrativas - em diferentes suportes. Esperamos, então, presentear os leitores com reflexões atuais sobre memória e sociabilidade, expressadas nos modos de pensar, criar, saber e fazer, e que incitam as nossas capacidades de irmos além do que presenciamos e pensamos sobre as práticas, colocando-nos na condição de Homo faber.

\section{REFERÊNCIA}

Alves, G. 2015. Animal Laborens e Homo faber, in Entre ofícios e profissões: reflexões antropológicas. Organizado por F. V. Nummer, e M. C. C. C. França, pp. 9-14. Belém: GAPTA. 